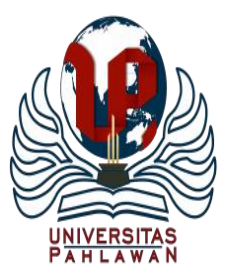

Edukatif : Jurnal Ilmu Pendidikan Volume 3 Nomor 1 Tahun 2021 Halm 102 - 108 EDUKATIF: JURNAL ILMU PENDIDIKAN

Research \& Learning in Education

https://edukatif.org/index.php/edukatif/index

\title{
Pemanfaatan Membatik Sederhana untuk Mengembangkan Kemampuan Motorik Halus Anak di Taman Kanak-kanak
}

\author{
Penuva Almi ${ }^{1 凶}$, Indra Yeni ${ }^{2}$ \\ Universitas Negeri Padang, Indonesia ${ }^{1,2}$ \\ E-mail : penuvaalmi11@gmail.com ${ }^{1}, \underline{\text { indrayeni.30031971@ @mail.com }}^{2}$
}

\begin{abstract}
Abstrak
Penelitian ini bertujuan untuk mendeskripsikan pemanfaatan membatik sederhana untuk mengembangkan kemampuan motorik halus anak di taman kanak-kanak Penelitian ini dikembangkan berdasarkan pada pentingnya perkembangan motorik halus pada anak usia dini. Pada anak usia dini di Taman Kanak-kanak kemampuan motorik halus masih rendah, terutama pada kegiatan pra menulis seperti cara memegang pensil yang masih kaku, menjiplak yang belum rapi, mewarnai yang masih telihat coretan. Motorik halus dapat dikembangkan dengan kegiatan membatik sederhana. Metode yang dipakai dalam penelitian ini adalah studi literature. Teknik pengumpulan data dengan menelaah sumber primer berupa buku, jurnal-jurnal, dan sumbersumber yang relevan lainnya. Metode pengumpulan data pusataka dengan membaca dan mencatat serta mengelola bahan penelitian lalu menyimpulkan bahan penelitian. Hasil peneliltian yang didapat bahwa pemanfaatan membatik sederhana dapat mengembangkan kemampuan motorik halus anak usia dini di Taman Kanak-kanak.
\end{abstract}

Kata kunci: pemanfaatan membatik sederhana, motorik halus, anak usia dini

\begin{abstract}
This research was developed based on the importance of fine motor development in early childhood. In PAUD in Kindergarten, his fine motor skills are still low, especially in pre-writing activities such as holding a pencil that is still stiff, tracing untidy objects, coloring that still looks scribbled. Fine motor skills can be developed with simple batik activities. This study aims to describe the use of simple batik to develop fine motor skills of children in Kindergarten. The method used in this research is literature study. Data collection techniques by examining primary sources in the form of books, journals, and other related sources. Centralaka's data collection method is by reading and taking notes and managing the research material and then concluding the research material. The results showed that the use of simple batik can develop fine motor skills for early childhood in Kindergarten.
\end{abstract}

Keywords: utilization of simple batik, fine motoric, early childhood

Copyright (c) 2021 Penuva Almi, Indra Yeni

$\triangle$ Corresponding author

Email : penuvaalmi11@gmail.com

DOI : https://doi.org/10.31004/edukatif.v3i1.249

ISSN 2656-8063 (Media Cetak)

ISSN 2656-8071 (Media Online) 
103 Pemanfaatan Membatik Sederhana untuk Mengembangkan Kemampuan Motorik Halus Anak di Taman Kanak-kanak - Penuva Almi, Indra Yeni

DOI: https://doi.org/10.31004/edukatif.v3i1.249

\section{PENDAHULUAN}

Anak usia dini ialah wujud orang yang lagi hadapi pertumbuhan yang sangat pesat untuk kehidupan mereka berikutnya. Anak usia dini terletak pada rentang umur baru lahir hingga umur 6 tahun yang diucap bagaikan umur emas (golden age). Anak usia dini merupakan anak yang lagi memerlukan upaya- upaya pembelajaran buat menggapai optimalisasi seluruh aspek pertumbuhan baik pertumbuhan raga ataupun psikis (Suryana, 2018). Anak usia dini merupakan orang yang lagi hadapi proses perkembangan serta pertumbuhan yang sangat pesat, apalagi dikatakan bagaikan lompatan pertumbuhan. Anak usia dini mempunyai rentang umur yang sangat berharga dibanding usia- usia berikutnya sebab pertumbuhan kecerdasannya sangat luar biasa (Mulyasa, 2014).

Anak usia dini butuh diberi stimulasi pada tiap aspek pertumbuhan dengan metode membagikan pembelajaran. Bagi Permendikbud No 146 Tahun 2014 Pasal 1 yang berbunyi“ PembelajaranAnak usia dini ialah jenjang pembelajaran saat sebelum jenjang pembelajaran dasar bagaikan sesuatu upaya pembinaan yang diperuntukan untuk anak semenjak lahir hingga dengan umur 6 tahun. Dicoba lewat pemberian rangsangan pembelajaran buat menolong perkembangan serta pertumbuhan jasmani dan rohani supaya anak mempunyai kesiapan dalam merambah pembelajaran lebih lanjut". Tujuan Pembelajaran Anak usia dini merupakan buat meningkatkan bermacam kemampuan anak semenjak dini bagaikan persiapan buat hidup serta bisa membiasakan diri dengan lingkungannya. Pembelajaran anak usia dini wajib mencermati aspek- aspek yang hendak dikembangan kepada anak ialah pertumbuhan kognitif, bahasa, Nilai agama serta moral, raga motoric, seni serta social emosional. Pertumbuhan kemampuan yang berarti dibesarkan pada anak salah satunya merupakan pertumbuhan motorik (Utami et al., 2019).

Motorik ialah salah satu aspek pertumbuhan yang terutama dibesarkan semenjak dini.Pertumbuhan motorik tumbuh dengan kematangan syaraf serta otot. Santrock (2007) mengemukakan keahlian motorik halus ialah keahlian motorik yang mengaitkan gerakan yang diatur secara halus. Menggenggam mainan, mengancingkan pakaian, ataupun melaksanakan apapun yang membutuhkan keahlian tangan menampilkan keahlian motorik halus. Bagi Putri et al. (2018) menarangkan pengembangan motorik halus anak ditekankan pada koordinasi gerakan motorik halus, dalam perihal ini berkaitan dengan aktivitas meletakkan ataupun memegang sesuatu objek dengan memakai jari tangan. Tujuan pertumbuhan motorik halus merupakan buat menggerakan jari jemari anak sehingga tidak kaku serta gampang dilekukkan supaya anak terampil serta teliti memakai jari jemari serta koordinasi mata serta tangan dalam kehidupan tiap hari.

Aktivitas yang bisa meningkatkan motorik halus anak ialah dengan aktivitas membatik yang dicoba dengan metode simpel. Bagi Ingkir et al. (2020) mengatakan kalau aktivitas membatik ialah salah satu aktivitas buat meningkatkan keahlian motoric halus anak. Dengan aktivitas membatik yang dicoba oleh anak wajib mempunyai kesabaran yang luar biasa, dalam diri anak supaya bisa menciptakan sesuatu karya yang menarik yang dicoba oleh anak dari menghias kain polos dengan metode menutup kain memakai tali buat mengikat bagian tali yang tidak di idamkan buat diwarnai. Bagi Winarsih (2019), aktivitas membatik merupakan proses penggambaran motif ataupun menjiplak pada kain bagaikan karakteristik khas batik. Bagi Penemuan Roostin (2020) mengemukakan salah satu metode buat tingkatkan keahlian otak kanan anak lewat kegiatan membatik simpel. Dengan belajar membatik simpel diharapkan bisa menghasilkan atmosfer belajar yang mengasyikkan serta berikan peluang kepada anak buat melatih motorik halus.Aktivitas membatik simpel berbeda dengan membatik pada biasanya, sebab membatik simpel membagikan peluang serta kebebasan buat mengeksplor bermacam berbagai perona yang nyaman untuk anak.Sehingga anak tidak terpaku pada perlengkapan tulis saja buat membuat suatu karya yang menarik.

Bersumber pada pengamatan di lapangan ditemui keahlian motoric halus anak masih rendah paling utama pada aktivitas pra menulis semacam metode memegang pensil yang masih kaku, menjiplak wujud 
ataupun garis yang belum apik, kesusahan membuat bentuk- bentuk tulisan serta memberi warna yang masih nampak coretan, dan aktivitas yang lain masih membutuhkan tutorial dari area paling utama keahlian motorik halus yang mencakup pemakaian koordinasi otot- otot halus. Sepanjang pengamatan di lapangan aktivitas yang bisa tingkatkan keahlian motorik halus anak usia dini semacam kolase, melekat, menggambar, memberi warna, usab abur serta membatik. Namun aktivitas membatik tidak sering diterapkan, sebab dikenal tidak tercapainya tujuan dari membatik yang diakibatkan kurang menariknya pendidikan di dalam kelas dan cuma memakai perlengkapan yang biasa saja.Hingga lewat aktivitas membatik simpel yang bisa meningkatkan motorik halus anak ialah dengan memakai perlengkapan yang simpel, nyaman untuk anak semacam spidol sisa, kuas sehingga membuat anak tertarik dengan perlengkapan serta bahan yang digunakan. Sehingga membuat pendidikan lebih efisien, mengasyikkan, anak pula bisa mengasil karya yang bagus, serta anak memahami batik bagaikan peninggalan budaya bangsa kita. Bersumber pada penjelasan tersebut hingga periset tertarik buat mempelajari memahami“ Pemanfaatan Membatik Simpel Buat Meningkatkan Keahlian Motorik Halus Anak Di Halaman Anak- anak". Lewat aktivitas ini anak diharapkan sanggup melenturkan jari jemari ataupun menggerakan otot- otot kecil disekitar tangan.

Tujuan penelitian ini adalah untuk mendeskripsikan pemanfaatan membatik sederhana untuk mengembangkan kemampuan motorik halus anak di Taman Kanak-Kanak.Motorik halus sangat penting dikembangkan sejak dini karena melalui motorik halus anak dapat melenturkan jari jemarinya. Melalui kegiatan membatik ini melibatkan koordinasi mata dan tangan sehingga dapat mengembangkan motorik halus anak.

\section{METODE PENELITIAN}

Jenis penelitian adalah studi literature dengan menelaah beberapa jurnal, buku, google books dan skripsi terkait dengan rumusan masalah. Embun dalam Mansyur et al. (2019) menjelaskan bahwa metode studi literature atau studi pustaka dilakukan berdasarkan atas karya tertulis termasuk hasil penelitian yang telah maupun yang belum dipublikasikan. Disebut penelitian studi pustaka karena data-data atau bahan-bahan yang diperlukan dalam menyelesaikan penelitian tersebut berasal dari perpustakaan baik berupa buku, ensiklopedia, kamus, jurnal, dokumen, majalah dan lain sebagainya. Hadi dalam (Harahap, 2014).

Menurut Sukardi (2008) menjelaskan mengenai macam-macam dokumen atau sumber literature yang digunakan adalah jurnal, laporan hasil penelitian, buku-buku, artikel ilmiah, dan sumber-sumber yang relevan lainnya.Dalam riset literature ini mencari rujukan teori yang relevan berisikan tentang" teorianak usia dini, teori membatik, serta teori motoric halus". Rujukan ini didapat lewat buku, jurnal- jurnal yang sudah di publish, google books, postingan serta skripsi. Riset literature ini bertujuan buat membangun serta mengkonstruksi konsepsi secara lebih kokoh berbasis penelitian- penelitian empiris yang sempat dicoba.

\section{HASIL DAN PEMBAHASAN PENELITIAN}

\section{Kegiatan Membatik Cap Sederhana Bagi Anak Usia Dini}

Bagi Wulandari (2011) batik ialah sesuatu metode dari proses penggambaran motif samapi pelorodan. Karakteristik khas batik pada metode penggambaran motif pada kain yang memakai proses pemalaman ialah menggoreskan malam ataupun parafin yang ditempatkan pada canting serta cap. Jadi batik ialah proses yang dicoba dengan menulis ataupun dengan melemparkan titik berulang kali pada kain. Batik pula ialah bahan kain yang sangat erat dengan nilai budaya warga, sehingga batik tidak saja bagaikan hasil penciptaan, namun pula ialah hasil budaya sesuatu warga. 
105 Pemanfaatan Membatik Sederhana untuk Mengembangkan Kemampuan Motorik Halus Anak di Taman Kanak-kanak - Penuva Almi, Indra Yeni

DOI: https://doi.org/10.31004/edukatif.v3i1.249

Sejalan dengan komentar di atas, Lisbijanto (2013) mengemukakan batik cap merupakan kain yang metode pembuatan warna serta motifnya dengan memakai cap ataupun semacam stempel yang dibuat dari tembaga. Cap tersebut mengambil alih guna canting dalam membatik, dengan cap ini hingga satu helai kain batik bisa dituntaskan dalam waktu pendek. Jadi batik cap ialah metode pembuatan motifnya dengan memakai cap ataupun stempel yang dicoba secara berulang- ulang.

Roostin (2020) mengemukakan membatik sederhana berbeda dengan membatik pada umumnya, dimana membatik pada umumnya menggunakan kain dan lilin malam yang panas yang dituliskan mengikuti pola melalui canting yang sudah tergambar di atas kain.Sedangkan membatik bagi anak usia dini dengan berbagai pewarna makanan yang kemudian diteteskan atau dicapkan pada kain polos menggunakan alat cap sehinggal menghasilkan motif pada kain. Jadi membatik cap sederhana bagi anak usia dini yaitu menggunakan alat dan bahan yang aman bagi anak.

Bagi Fatmala \& Hartati (2020) pendidikan membatik pada anak umur 5- 6 tahun merupakan metode guru buat membuat sesuatu aktivitas membubuhkan corak di atas permukaan datar yang ketebalannya tidak turut diperhitungkan (karya 2 dimensi) buat menuangkan ide kreatif ataupun perasaan kedalam wujud pewarnaan, dengan sediakan sarana aktivitas tersebut. Sehingga anak yang belum menguasai bahan ajar serta belum mempunyai keahlian sehabis memperoleh pendidikan dari guru, anak berganti jadi menguasai modul bahan ajar dan mempunyai keahlian. Keahlian tersebut meliputi pengkoordinasian mata serta tangan.Jadi pendidikan membatik buat anak umur 5- 6 tahun ialah pendidikan membatik simpel serta memakai media yang nyaman untuk anak.

\section{Pemanfaatan Membatik Bagi Anak Usia Dini}

Rahayu (2010) mengemukakan manfaat kegiatan membatik, anak akan belajar mengenal karya seni dan anak juga dapat mencintai serta melestarikan warisan nenek moyang yaitu kegiatan membatik. Selain itu, kegiatan membatik juga bagus untuk meningkatkan perkembangan motoric anak, yaitu koordinasi tangan maupun mata, keterampilantangan anak akan belajar mengerjakan tugas hingga mencapai hasil yang diinginkan dengan rasa tanggung jawab. Melalui kegiatan ini anak juga akan menciptakan pola-pola yang menarik dan akan memberikan kepercayaan pada diri anak. Menurut Prasetyono dalam Ikawati, Saparahayuningsih, and Yulidesni (2017) manfaat kegiatan membatik untuk anak usia dini merupakan kegiatan yang melibatkan koordinasi mata dan tangan. Kegiatan membatik menciptakan pola-pola yang sangat menarik, danmemberikan kepercayaan diri pada anak. Jadi manfaat membatik bagi anak usia dini yaitu untuk meningkatkan perkembangan motoric halus yang melibatkan jari-jemari anak dan juga melatih konsentrasi dan kesabaran anak untuk menghasilkan pola yang bagus.

Menurut Prasetyono (2008) manfaat kegiatan membatik untuk anak usia dini merupakan kegiatan yang melibatkan koordinasi mata dan tangan. Kegiatan membatik menciptakan pola-pola yang sangat menarik, danmemberikan kepercayaan diri pada anak. Kemudian diperkuatdengan pendapat Roostin (2020) mengemukakan kegiatan membatik sederhana bermanfaat untuk meningkatkan kemampuan otak kanan anak melalui aktivitas membatik sederhana. Dengan belajar membatik sederhana diharapkan dapat menciptakan suasana belajar yang menyenangkan dan memberi kesempatan pada anak untuk melatih motoric halus.

\section{Cara dan Langkah-Langkah dalam Kegiatan Membatik Cap Sederhana}

Cara dan langkah-langkah dalam kegiatan membatik cap sederhana yaitu pertama, yang dilakukan adalah persiapan. Persiapan dimulai dengan guru menjelaskan langkah-langkah dalam kegiatan membatik cap dingin sederhana dan mempersiapakan alat dan bahan yang akan digunakan. Kedua, yaitu inti dari kegiatan membatik cap dingin sederhana. Pada pelaksanaan guru terlebih dahulu menjelaskan dan memberi contoh teknik membatik cap dingin sederhana yang akan dilakukan. Langkah-langkah dalam membatik cap dingin sederhana dimulai dari: 1) Anak-anak diminta terlebih dahulu memakai celemek dan mengalas meja dengan 
106 Pemanfaatan Membatik Sederhana untuk Mengembangkan Kemampuan Motorik Halus Anak di Taman Kanak-kanak - Penuva Almi, Indra Yeni

DOI: https://doi.org/10.31004/edukatif.v3i1.249

koran bekas. 2) Guru membagikan bahan dan alat yang digunakan dalam kegiatan membatik cap dingin sederhana. 3) Anak-anak diminta untuk mencampurkan tepung, pewarna makanan dan air sebagai pasta. 4) Selanjutnya anak-anak melakukan kegiatan mencap ujung tutup spidol ke pasta yang sudah dibuatnya. 5) Setelah anak-anak mencapkan ke ujung spidol, lalu di angkat dan anak mencapkannya langsung ke buku gambar yang sudah ada gambar baju sesuai keinginan anak masing-masing. Ketiga, tahap terakhir yaitu penutupan. Anak bersama guru untuk merapikan kembali alat dan bahan yang telah digunakan.Anakdan guru mencuci tangan setelah merapikan alat dan bahan yang digunakan. Setelah itu hasil karya anak dijemur hingga kering

\section{Motorik Halus Anak Usia Dini}

Kemampuan fisik motoric merupakan kemampuan dasar yang harus dikembangkan sejak dini.Kemampuan fisik motoric berperan penting dalam perkembangan dan pertumbuhan anak.Perkembangan motoric berkembang dengan kematangan syaraf dan otot.Perkembangan motoric pada anak juga terbagi dua yaitu motoric kasar dan motoric halus.Motoric kasar merupakan gerakan yang berhubungan dengan otot besar seperti berlari, berjalan, melompat dan sebagainya.Sedangkan motoric halus melibatkan otot kecil seperti menulis, memegang, menempel, dan lain-lain.

Bagi Wulan (2011) melaporkan kalau keahlian motorik tangan berkaitan dengan keahlian buat mengatur otot- otot tangan, jari- jari tangan, bahu serta pergelangan tangan. Sebagian tipe keahlian tangan yang banyak diteliti oleh para pakar merupakan keahlian buat makan, menjaga diri sendiri, menulis, menjiplak, melontarkan serta menangkap bola dan membuat konstruksi yang rumit. Jadi motoric halus untuk anak usia dini ialah keahlian anak dalam beraktifitas dengan mengaitkan otot- otot kecil pada jari- jarinya serta koordinasi antara mata serta tangan.

Menurut Sujiono (2009) tujuan motorik halus adalah mampu memfungsikan otot-otot kecil seperti gerakan dari jemari tangan, koordinasi mata dan tangan serta membuat anak dapat berkreasi seperti menulis, menggambar dan mewarnai. Menurut Rakimahwati (2012) menjelaskan pengembangan motorik halus anak ditekankan pada koordinasi gerakan motorik halus, dalam hal ini berkaitan dengan kegiatan meletakkan atau memegang suatu objek dengan menggunakan jari tangan. Jadi tujuan motoric halus untuk menggerakan jari jemari anak sehingga tidak kaku dan mudah dilekukkan agar anak terampil dan cermat menggunakan jari jemari dan koordinasi mata dan tangan dalam kehidupan sehari-hari.

\section{Analisis Pemanfaatan Membatik Sederhana Untuk Mengembangkan Kemampuan Motorik Halus Anak Di Taman Kanak-Kanak}

Berdasarkan pembahasan mengenai membatikdan kemampuan motoric halus anak usia dini diatas dapat dianalisis bahwa : Pertama, melalui kegiatan membatik cap sederhana ini dapat mengembangkan kemampuan motorik halus anak yaitu melalui kegiatan mencap atau menempelkan dan memegang alat membatik, serta cara anak mencampurkan warna lalu mengaduknya pada saat melakukan kegiatan membatik cap sederhana. Kegiatan membatik cap sederhana ini dapat membuat otot-otot kecil anak atau disekitar jari-jemari anak berfungsi ketika anak memegang dan mencap adagerakan-gerakan disana. Semakin anak melakukan berulangulang, tangan anak atau otot-otot kecil anak akan berkembang.

Kedua, kegiatan membatik cap sederhana sangat cocok sebagai media pembelajaran anak usia dini karena alat yang digunakan aman dan mudah didapatkan dan kegiatan ini juga menyenangkan bagi anak sehingga meningkatkan hasil belajar anak. Dengan adanya kegiatan membatik dalam perkembangan motoric halus pada anak, tanpa disengaja anak dapat mengenal batik-batik sederhana, dapat membuat batik sederhana sesuai kemampuan dan tahap usia anak. Ketiga, melalui kegiatan membatik cap sederhana ini dapat melatih konsentrasi dan kesabaran anak untuk menyelesaikannya. Dengan adanya lingkungan yang mendukung anak untuk mengembangkan motorik halus akan membuat anak lebih berkonsentrasi terhadap perkembangan fisik 
107 Pemanfaatan Membatik Sederhana untuk Mengembangkan Kemampuan Motorik Halus Anak di Taman Kanak-kanak - Penuva Almi, Indra Yeni

DOI: https://doi.org/10.31004/edukatif.v3i1.249

motoriknya. Sehingga anak juga dapat menghasilkan karya yang bagus. Melalui kegiatan membatik sederhana ini juga mengajarkan kepada anak untuk bekerja sama dan Tanya jawab ketika guru melakukan kegiatannya dan juga menambahkan pengalaman baru bagi anak.

\section{KESIMPULAN}

Pemanfaatan membatik sederhana dapat membantu mengembangkankemampuan motorik halus anak usia dini. Kemampuan motorik halus anak usia dini dengan pemanfaatan membatik sederhana dapat mendorong anak untuk melenturkan jari-jarinya, anak dapat mencap berulang-ulang kali sesuai kemampuan motoric halus anak, anak juga dapat memegang media yang digunakan, melakukan kegiatan membatik cap sederhana sesuai ide atau imajinasi yang ada dipikirannya, dan anak juga dapat berkreasi dengan mencampurkan warna yang disukai anak. Membatik sederhana ini bisa menjadi salah satu kegiatan yang digunakan guru dalam mengembangkan kemampuan motorik halus anak sehingga kegiatan yang diberikan guru kepada anak tidak yang itu-itu saja. Membatik cap sederhana menggunakan spidol merupakan kegiatan yang menyenangkan dimana anak di ajak untuk bermain warna dan mencobakan suatu hal yang jarang atau belum pernahdi cobakan. Selain dilakukan di sekolah orang tua juga bisa melakukannya dirumah bersama anak dengan menggunakan cat dan memanfaatkan barang bekas yang ada dirumah sebagai alat cap untuk kegiatan membatik cap yang sederhana.

\section{DAFTAR PUSTAKA}

Fatmala, Y., \& Hartati, S. (2020). Pengaruh Membatik Ecoprint terhadap Perkembangan Kreativitas Seni Anak di Taman Kanak-Kanak Islam Budi Mulia Padang. Jurnal Pendidikan Tambusai, 4(2). file:///C:/Users/lenovo/AppData/Local/Temp/65-705-1-PB.pdf

Harahap, N. (2014). Penelitian Kepustakaan. Jurnal Iqra', 08(01). file://C:/Users/lenovo/AppData/Local/Temp/65-705-1-PB.pdf

Ikawati, K., Saparahayuningsih, S., \& Yulidesni, Y. (2017). Meningkatan Keterampilan Motorik Halus Anak Melalui Kegiatan Pembelajaran Membatik Menggunakan Media Tepung Pada Anak Kelompok B PAUD Aisyiyah III Kota Bengkulu. Jurnal Ilmiah Potensia, 2(2), 91-94. https://doi.org/10.33369/jip.2.2

Ingkir, Y., Wondal, R., \& Arfa, U. (2020). Kegiatan Membatik dalam Mengembangkan Kemampuan Motorik Halus Anak. Jurnal Pendidikan Guru Pendidikan Anak Usia Dini, 3(1). file://C:/Users/lenovo/AppData/Local/Temp/2043-5942-1-PB.pdf

Lisbijanto, H. (2013). Batik. Graha Ilmu.

Mansyur, A. I., Chairunnisa, D., \& Hidayat, D. R. (2019). Implementasi Teori Super pada Program Layanan Bimbingan dan Konseling Karir untuk Mahasiswa Perguruan Tinggi. Jurnal Psikologi Konseling, 15(2). https://jurnal.unimed.ac.id/2012/index.php/Konseling/article/view/16197/12649

Mulyasa. (2014). Manajemen PAUD.

Prasetyono, D. S. (2008). Biarkan Anakmu Bermain. Diva Press.

Putri, M., Rakimahwati, R., \& Zulminiati, Z. (2018). Efektivitas Penerapan Metode Bermain Peran Makro Terhadap Perkembangan Bahasa. Journal of SECE (Studies in Early Chilhood Education), 1(2), 171179. file:///C:/Users/lenovo/AppData/Local/Temp/730-133-3057-2-10-20181130.pdf

Rahayu, L. (2010). 20 Fun Activites For Toddler. Indiparent.

Rakimahwati, R. (2012). Model Pembelajaran Sambil Bermain pada Pendidikan Anak Usia Dini. UNP Press.

Roostin, E. (2020). Upaya Meningkatkan motorik Halus dan Kreativitas anak Melalui Teknik Membatik Sederhana. KIDDO: JURNAL PENDIDIKAN ISLAM ANAK USIA DINI, I(2). 
108 Pemanfaatan Membatik Sederhana untuk Mengembangkan Kemampuan Motorik Halus Anak di Taman Kanak-kanak - Penuva Almi, Indra Yeni

DOI: https://doi.org/10.31004/edukatif.v3i1.249

http://ejournal.iainmadura.ac.id/index.php/kiddo/article/view/3481/pdf

Santrock, J. (2007). Perkembangan Anak (11th ed.). Erlangga.

Sujiono, Y. N. (2009). Konsep Dasar Pendidikan Anak Usia Dini. PT Indeks.

Sukardi. (2008). Metodologi Penelitian Pendidikan, Kompetensi dan Praktiknya. Bumi Aksara.

Suryana, D. (2018). Pendidikan Anak Usia Dini Stimulasi dan Aspek Perkembangan Anak. Prenadamedia Group.

Utami, F. P., Yeni, I., \& Rakimahwati, R. (2019). Efektivitas Penggunaan Jari Tangan dalam Mengembangkan Motorik Halus Anak di Taman Kanak-kanak Bhayangkari 1 Padang. Journal On Teacher Education, 1(1), 45-56. file:///C:/Users/lenovo/AppData/Local/Temp/504-956-1-SM.pdf

Winarsih, W. (2019). Peningkatan Keterampilan Motorik Halus Melalui Kegiatan Membatik. Jurnal Inovatif Ilmu Pendidikan, 1(1), 24-35. file:///C:/Users/lenovo/AppData/Local/Temp/2043-5942-1-PB.pdf

Wulan, R. (2011). Mengasah Kecerdasan Anak. Pustaka Pelajar.

Wulandari, A. (2011). Batik Nusantara: Makna Filosofis Cara Pembuatan dan Industi Batik. Andi Offset. 